\title{
Taxonomic notes on five species of Gracilariaceae from Hainan, China
}

\author{
Mi Yeon Yang ${ }^{1}$, Jun-De Dong ${ }^{2}$ and Myung Sook Kim ${ }^{1, *}$ \\ ${ }^{1}$ Department of Biology and Research Institute for Basic Sciences, Jeju National University, Jeju 690-756, Korea \\ ${ }^{2}$ Tropical Marine Biological Research Station in Hainan, South China Sea Institute of Oceanology, Chinese Academy of \\ Science, Guangzhou 510301, China
}

Hainan is the second largest and southernmost island of China, and it harbors many species of the family Gracilariaceae. In this study, we conducted molecular and morphological analyses of gracilarian specimens collected from Hainan Island, to clarify their taxonomic identity and phylogenetic relationships. Five species of Gracilariaceae in Hainan were determined through maximum likelihood and Bayesian analysis of $r b c \mathrm{~L}$ sequence data. Based on the phylogenetic trees and morphology, Hainan specimens were identified as three species of Gracilaria, one species of Gracilariopsis, and one species of Hydropuntia, namely, G. salicornia, G. tenuistipitata, Gracilaria sp., Gp. bailiniae and H. edulis. This is the first report of the molecular phylogeny of Gracilariaceae on Hainan Island, and it helps to clarify the taxonomy and distribution of gracilarian species in the Asia-Pacific region.

Key Words: Gracilariaceae; Hainan; phylogeny; rbcL; Rhodophyta; taxonomy

\section{INTRODUCTION}

The family Gracilariaceae Nägeli belongs to Gracilariales, the order of marine red algae described by Fredericq and Hommersand (1989). The gracilarioid algae include some of the most valuable marine plants. They have been extensively investigated over the last 30 years, and many studies have provided comprehensive information on their life history, cultivation, taxonomy, and utilization (Bellorin et al. 2002, Rueness 2005). Studies on the structure of their reproductive organs and the phylogenetic relationships among species inferred from $r b c \mathrm{~L}$ sequence analyses have produced three clades at the genus level, namely Gracilaria sensu stricto, Gracilariopsis, and Hydropuntia (Gurgel and Fredericq 2004). However, the wide phenotypic variability of the terete species in the Gracilariaceae has made it difficult to define the species boundary of this group.

DNA sequence analysis is the most widely used mo- lecular technique for inferring phylogenetic relationships at the species level within the Gracilariaceae (Iyer et al. 2005, Gargiulo et al. 2006, Bellorin et al. 2008, Kim et al. 2008a). It is a useful taxonomic tool for distinguishing between organisms that are difficult to identify based on morphological characteristics only. A global phylogeny and taxonomic biogeography of Gracilariaceae has been conducted (Bellorin et al. 2002, Gurgel and Fredericq 2004, Guillemin et al. 2008). Based on these studies, both Gracilaria and Gracilariopsis have been confirmed to be monophyletic groups, whereas Hydropuntia has received less support as a monophyletic group (Gurgel and Fredericq 2004). Recently, DNA barcoding has become an important tool for the identification of gracilarioid species (Saunders 2009, Kim et al. 2010). Many genes such as small subunit (SSU) rRNA, RUBISCO spacer, cox2-3 spacer, and $c o x 1$ have been used for phylogenetic inference (c) This is an Open Access article distributed under the terms of the Creative Commons Attribution Non-Commercial License (http://creativecommons.org/licenses/by-nc/3.0/) which permits unrestricted non-commercial use, distribution, and reproduction in any medium, provided the original work is properly cited.
Received June 25, 2012, Accepted August 4, 2012

*Corresponding Author

E-mail: myungskim@jejunu.ac.kr

Tel: +82-64-754-3523, Fax: +82-64-756-3541 
and the chloroplast-encoded $r b c \mathrm{~L}$ gene is well suited and widely used for phylogenetic reconstructions at the species level (Kim et al. 2006, Kim et al. 2008b).

In China, there are several papers on the morphological description of Gracilariaceae with 14 novel species (Chang and Xia 1976, Zhang and Xia 1988, 1992, 1994), particularly Chang and Xia (1976) dealt with 24 species of the genus Gracilaria collected from the China coast. Hainan is the second largest and southernmost island in China and it is also located in the northern periphery of the subtropical Asia-Pacific region. Due to its geographical location, several novel gracilarian species have been reported in Hainan, as the type locality of eight species: for example G. tenuistipitata Chang et Xia and Gracilariopsis bailiniae Zhang et Xia (as G. heteroclada). Although many species of Gracilariaceae have been described from China, the species diversity and phylogenetic relationships based on the molecular analyses have not been yet conducted in Hainan Island.

This study was performed as part of survey on the gracilarian species diversity in Asia-Pacific region and focused on the molecular phylogeny of Gracilariaceae on Hainan Island for the first time. We conducted molecular and morphological analyses to clarify their taxonomic identities and better understand their distributions. As a result, we reported the phylogenetic relationships of five species: Gracialria salicornia, G. tenustipitata, Gracilaria sp., Gracilariopsis bailiniae, and Hydropuntia edulis. These are distinct from all currently known species in the family Gracilariaceae.

\section{MATERIALS AND METHODS}

Gracilariaceae specimens were collected from intertidal substrates in Sanya, Hainan, China: G058 (JN605794), January 29, 2010, Matou; G056 (JN605796), January 30, 2010, Xiadonghai Bay; G052 (JN605793), January 31, 2010, Hongsha River; G057 (JQ026028), January 31, 2010, Yulin Harbor; G054 (JN605795), January 29, 2010, Qingshui Bay. Specimens were air-dried and stored in silica gel desiccant for DNA extraction. Voucher specimens are housed at the herbarium of Jeju National University (JNUB), Jeju, Korea. Specimen slides were stained with aniline blue solution and examined for morphological diagnostic features. Photographs were taken using a $\mu$-Tough- 8000 digital camera (Olympus, Tokyo, Japan), and QIMAGING 1394 (QImaging, Surrey, BC, Canada) with a BX50 microscope (Olympus). After obtaining the digital images, plates were edited using Photoshop 7.0.1 (Adobe, San Jose, CA, USA).
Total genomic DNA was extracted from dried thalli ground in liquid nitrogen using the DNeasy Plant Mini Kit (Qiagen, Hilden, Germany), according to the manufacturer's protocol. For amplification and sequencing of the $r b c \mathrm{~L}$ gene, the following specific primer pairs were used: $r b c \mathrm{LF} 7-r b c \mathrm{LR} 753$ and $r b c \mathrm{LF} 645-r b c \mathrm{~S}$ start (Gavio and Fredericq 2002). All PCR amplifications were carried out using Swift MaxPro thermal cyclers (ESCO, Singapore) and AccuPower PCR PreMix (Bioneer, Daejeon, Korea) in a total volume of $20 \mu \mathrm{L}$. Amplified products were purified using the AccuPrep PCR Purification Kit (Bioneer) and were then sequenced commercially (Macrogen, Seoul, Korea). Both electropherogram outputs from each sample were edited using Chromas version 1.45. Total $r b c \mathrm{~L}$ sequences were organized using the multiple-sequence editing program BioEdit (Hall 1999) and aligned visually.

To confirm the taxonomic position of Gracilariaceae from Hainan, maximum likelihood (ML) and Bayesian analysis (BA) were performed using PAUP 4.0 (Swofford 2002) and MrBayes v.3.1.2 (Ronquist and Huelsenbeck 2003). Five $r b c \mathrm{~L}$ sequences were aligned with other Gracilariaceae species, and two genera, Curdiea crassa [AY049427] and Melanthalia obtusata [AY046431], were used as an outgroup. We tested likelihood ratios using MODELTEST version 3.7 (Posada and Crandall 1998) to determine the best available model for our sequence data, which was a general time reversible (GTR) model with gamma correction for among-site variation $(\Gamma)$ and the proportion of invariable sites (I). ML trees were estimated using a heuristic search with 100 random-addition sequence replicates and tree bisection-reconection (TBR) branch swapping. To test the node stability, ML bootstrap analyses were performed with 1,000 replicates. Bayesian analysis was conducted with the Metropolis coupled Markov chain Monte Carlo ( $\left.\mathrm{MC}^{3}\right)$ for individual data sets. We performed two million generations of two independent runs with four chains, and sampled every 100 generations. The "burn-in" point was identified graphically by tracking the likelihoods at each generation. The remaining trees were used to calculate a posterior probability tree topology.

\section{RESULTS AND DISCUSSION}

\section{Gracilaria salicornia (C. Agardh) Dawson (Fig. 1)}

Description. Thallus ranges from being erect to prostrate, $2-4 \mathrm{~cm}$ tall, forming a loose tuft-like aggregation from the discoid holdfast (Fig. 1B \& C). The texture is car- 

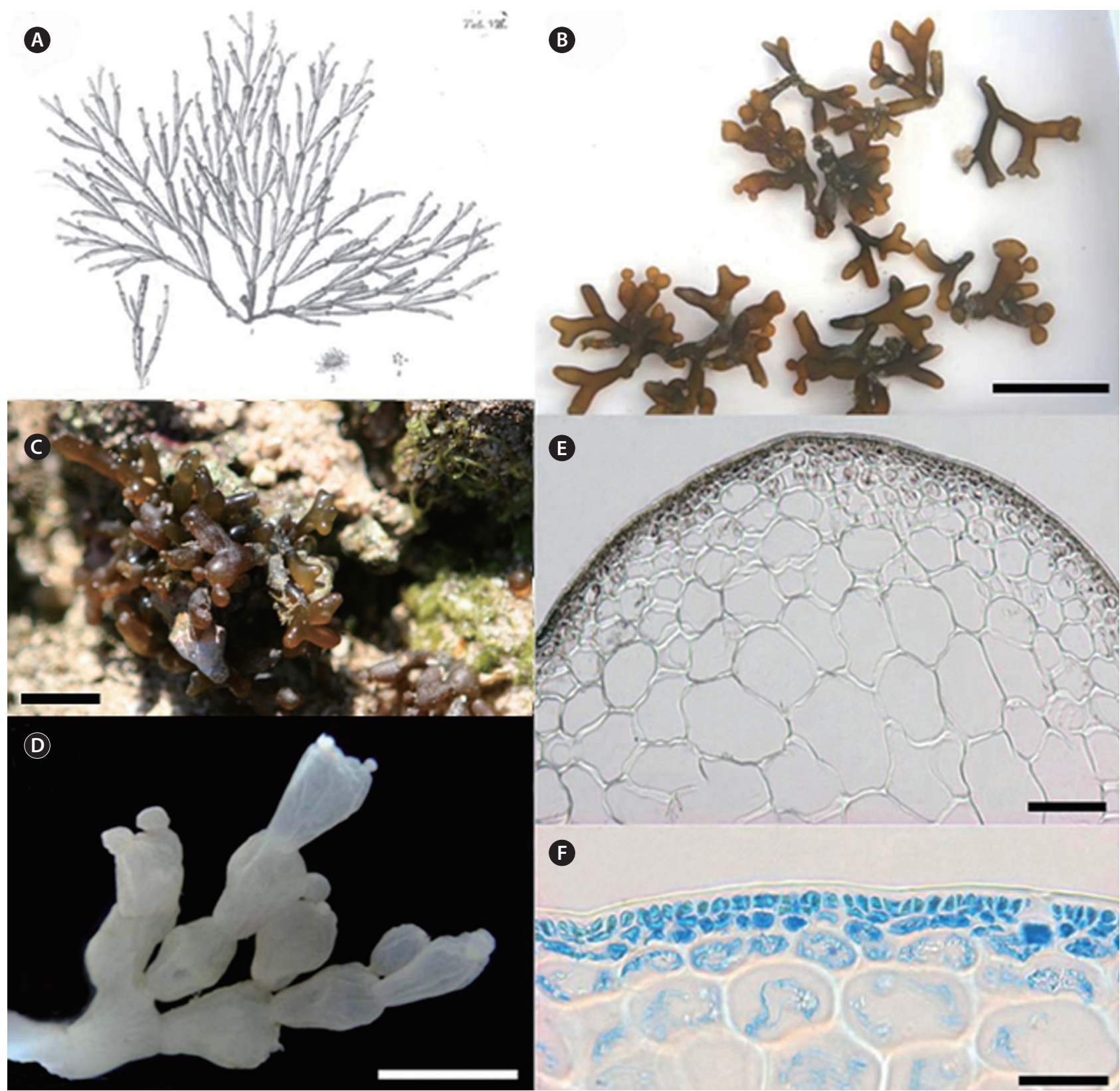

(F)

Fig. 1. Gracilaria salicornia (C. Agardh) Dawson. (A) Holotype photo cited from C. Agardh 1820. (B) Specimen collected from Xiadonghai bay, Sanya, Hainan in January 30, 2010. (C) Photograph showing the habitat of specimens growing on the rock. (D) Shape of the apical part of branches showing the constricted segments. (E \& F) Transverse section of branches showing gradual transition of cells from medulla to cortex with thin-wall and small-celled cortex. Scale bars represent: B \& C, $2 \mathrm{~cm} ; \mathrm{D}, 1 \mathrm{~cm} ; \mathrm{E}, 200 \mu \mathrm{m} ; \mathrm{F}, 50 \mu \mathrm{m}$.

tilaginous and succulent, and it is light brown to orange in color. Cylindrical branches are distinctly constricted at the base with two branchlets at each node and smooth margins 2-2.5 mm in diameter (Fig. 1D). Branchlets are elongated, club-shaped, and generally di- to trichotomously arranged. The medullary cells gradually increase in diameter toward the center (Fig. 1E). The medullary cell is $200-400 \mu \mathrm{m}$ in diameter, with walls approximately $10-15 \mu \mathrm{m}$ thick. The cortical layer consists of 2-3 small cells that are 7-10 $\mu \mathrm{m}$ in diameter (Fig. 1F).

Basionym. Sphaerococcus salicornia C. Agardh 1820.

Type locality. Manila, the Philippines. 
Distribution. Asia (Xia 1985, Ohno et al. 1999), Pacific Islands (Meneses and Abbott 1987), Australia (Witherell et al. 1994, Millar and Xia 1997), Indian Ocean (Silva et al. 1996), Africa (Silva et al. 1996).

Remarks. Gracilaria salicornia (C. Agardh) Dawson (1954) was first described as Sphaerococcus salicornia by C. Agardh (1820), characterized by having articulate fronds and clavate branches (Fig. 1A). This species was transferred to the genus Corallopsis and termed C. salicornia by Greville (1830). He distinguished two genera, Corallopsis and Gracilaria, by the extreme branch constriction of Corallopsis. Dawson (1954) merged Corallopsis to the genus Gracilaria, because articulation or constriction of branches is insufficient for separating genera.

Xia (1986) recognized that the degree of constriction at the branch base was not distinguishable among similar species, such as G. canaliculata Sonder (= G. crassa Harvey ex J. Agardh), G. cacalia (J. Agardh) E. Y. Dawson, G. minor (Sonder) Durairatnam, and G. opuntia Durairatnam. Thus, she merged these four species into G. salicornia. Recently, Iyer et al. (2005) confirmed that G. canaliculata Sonder is a taxonomic entity based on the molecular evidence of $18 \mathrm{~S}$ rDNA and RUBISCO spacer sequence data, though the morphology of the species is similar to G. salicornia. The articulated and constricted segments of G. salicornia are very distinctive characteristics compared to other species of Gracilaria. G. salicornia was collected in Xiadonghai bay, Sanya, on January 30, 2010. It was growing on bedrock in a tide pool with coral (Fig. 1C). The $r b c \mathrm{~L}$ sequences generated from this specimen have a $0.2 \%$ intraspecific divergence with those of specimens from the Philippines, the type locality.

\section{Gracilaria tenuistipitata C. F. Chang et B. M. Xia (Fig. 2)}

Description. Plants are 10-20 cm long, slender, with 2-3 orders of branching and easily detached from the substratum because of the small holdfast and slender stipe (Fig. 2A). Main axes have densely and irregularly arranged branches that bear progressively shorter, delicate, and numerous branchlets of 1.0-1.5 $\mathrm{mm}$ in diameter (Fig. 2B). The medulla consists of 4-5 cells that increase markedly in size towards the center and reaches up to 130-200 $\mu \mathrm{m}$ in diameter, with thick walls of 10-25 $\mu \mathrm{m}$ in diameter (Fig. 2D). The cortex consists of 1-2 layers of rounded cells of 14-22 $\mu \mathrm{m}$ in diameter (Fig. 2E).

Type locality. (as G. tenuistipitata var. tenuistipitata) Bohe, Dianbai Xian, Guangdong Province, China.

Distribution. Asia (Ohno et al. 1999, Terada et al. 2000).
Remarks. Its distribution is restricted to China, Malaysia, Thailand, and Vietnam. Two varieties, G. tenuistipitata var. tenuistipitata Chang et Xia (1976) and var. liui Zhang et Xia (1988), are recognized and both originally are described from Guandong Province, China. G. tenuistipitata var. tenuistipitata has a few elongated lateral branches on the main axis in a loose spiral arrangement, whereas G. tenuistipitata var. liui has slender thalli bearing numerous, delicate, short to long flagelli-form lateral branchlets. This latter variety frequently occurs naturally in fish ponds and shallow intertidal muddy areas, and is more common than var. tenuistipitata in the field (Zhang and Xia 1988, Ohno et al. 1999). Zhang and Xia (1988) suggested that var. liui has multiple branches, whereas var. tenuistipitata has only a small number of lateral branches.

The G. tenuistipitata specimen was collected from Hongsha river, Sanya, on January 31, 2010. It was growing on a muddy substratum in a shallow intertidal zone near a mangrove (Fig. 2C). In the phylogenetic tree, the clade $G$. tenuistipitata was resolved with strong support for ML (100\%) and BA (100\%) analyses of $r b c \mathrm{~L}$ sequence data (Fig. 6). Gracilaria chilensis C. J. Bird, McLachlan, \& E. C. Oliveira from Chile formed a sister group with the clade of $G$. tenuistipitata in a $100 \%$ bootstrap value for ML and BA. The interspecific divergence between G. chilensis and G. tenuistipitata was $8.7-9.1 \%$, and the intraspecific divergence of G. tenuistipitata was $0.1-1.0 \%$.

\section{Gracilaria sp. (Fig. 3)}

Description. Plants are solitary, up to $15 \mathrm{~cm}$ in length, and erect axes rise from small discoid holdfasts (Fig. 3A). Branches are terete and always constricted at the base (Fig. 3B), tapering gradually towards acute apices (Fig. 3C). The cortex consists of globular cells with a dense cytoplasm, $9 \mu \mathrm{m}$ high and $7 \mu \mathrm{m}$ wide in size. The medulla consists of 7-8 cells with thin-walled (15 $\mu \mathrm{m})$, unpigmented, spherical or isodiametric cells. Medullary cells increase abruptly in size toward the center, reaching up to $600 \mu \mathrm{m}$ in diameter (Fig. 3D). Cystocarps prominently protrude from the entire surface, except the basal and apical parts (Fig. 3E). They are globose, $900 \mu \mathrm{m}$ high and $1,100 \mu \mathrm{m}$ wide, slightly constricted at the base, and have tubular nutritive cells connecting gonimoblasts to the pericarp (Fig. 3E). Pericarp tissue is $200-230 \mu \mathrm{m}$ thick, and carposporangia is globose to obovoid and 17-20 $\mu \mathrm{m}$ in diameter. Only cystocarpic plants were collected at Matou, Sanya, on January 29, 2010, growing on sand in the intertidal zone. 


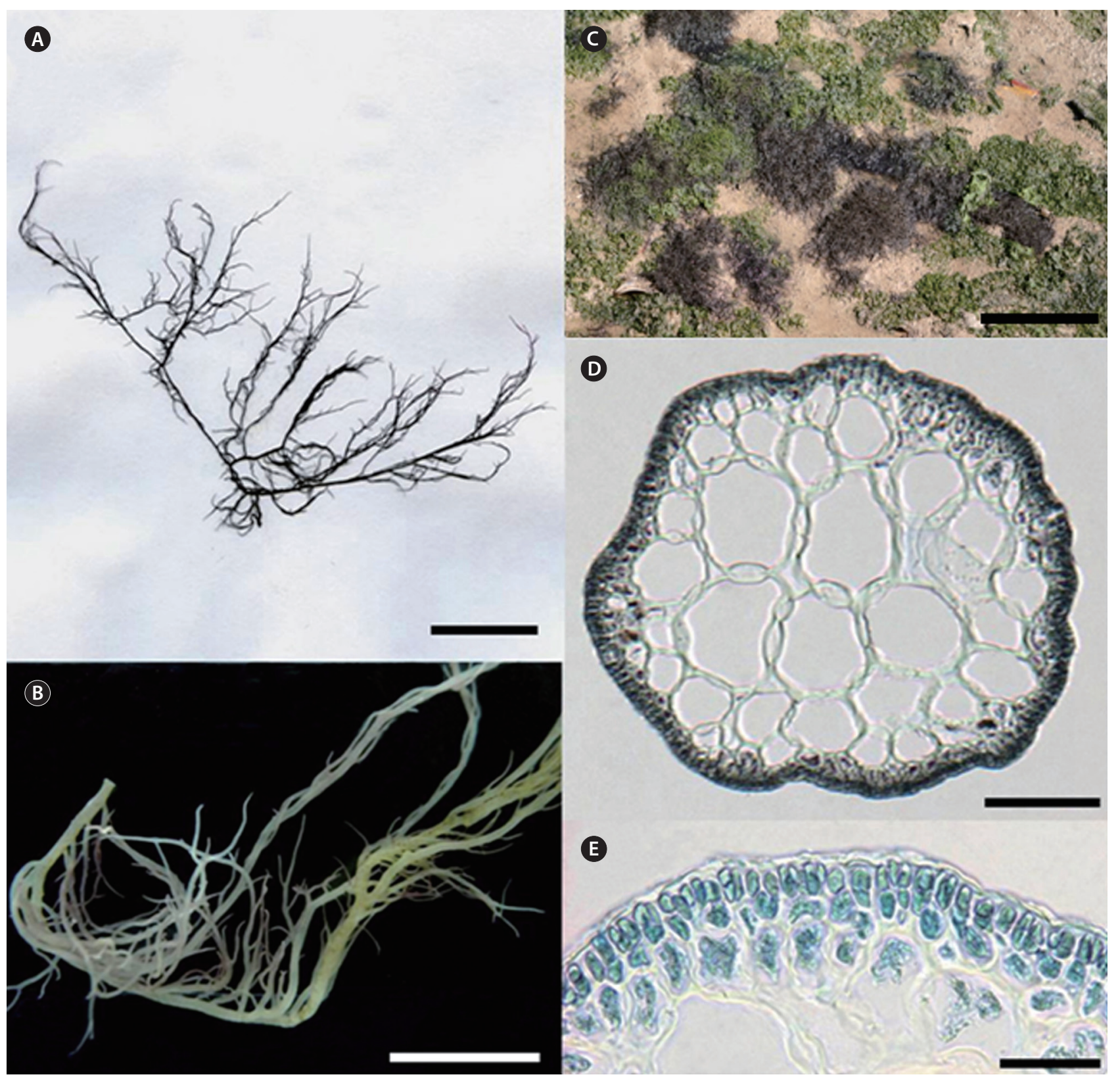

Fig. 2. Gracilaria tenuistipitata C. F. Chang et B. M. Xia. (A) Herbarium specimen collected from Hongsha river, Hainan in January 31, 2010. (B) A part of the main axis bearing many terminal branchlets. (C) Habitat of specimens growing in the muddy. (D \& E) Transverse section of the branch showing the abrupt transition in medullary cell to cortical cell size with thick-wall and small-celled cortex. Scale bars represent: $A, 2 \mathrm{~cm} ; \mathrm{B}, 1 \mathrm{~cm} ; \mathrm{C}$, $15 \mathrm{~cm} ; \mathrm{D}, 200 \mu \mathrm{m} ; \mathrm{E}, 50 \mu \mathrm{m}$.

Gracilaria sp. resembles G. articulata, G. blodgettii and G. firma because they are superficially similar in their branching pattern, especially in the remarkable constriction at the base of branches. Terada and Shimada (2005), however, mentioned that the intercalary articulations are present only in G. articulata, and the blunt apices of the branches in G. articulata are also different from the acute apices of G. blodgettii. They confirmed morphological differences for two species using the result of molecular analyses, such as cox2-3 and Rubisco spacer. G. firma was found to be different from G. blodgettii in having thin medullary cell wall (Chang and Xia 1976). In this study, our specimen collected from Hainan did not correspond to any species in the results of $c o x 2-3$ spacer and $r b c \mathrm{~L}$ 


\section{A}
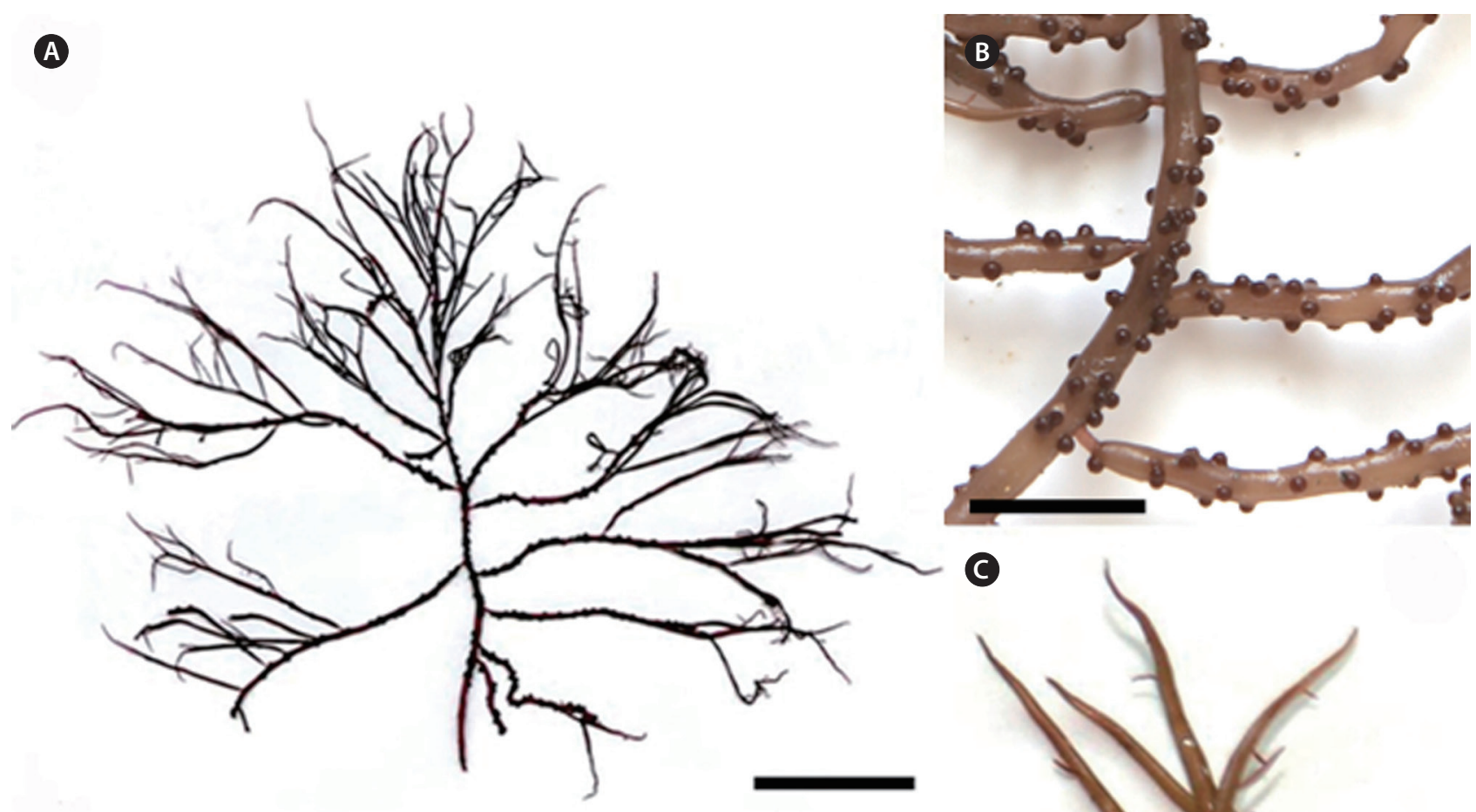

(D)

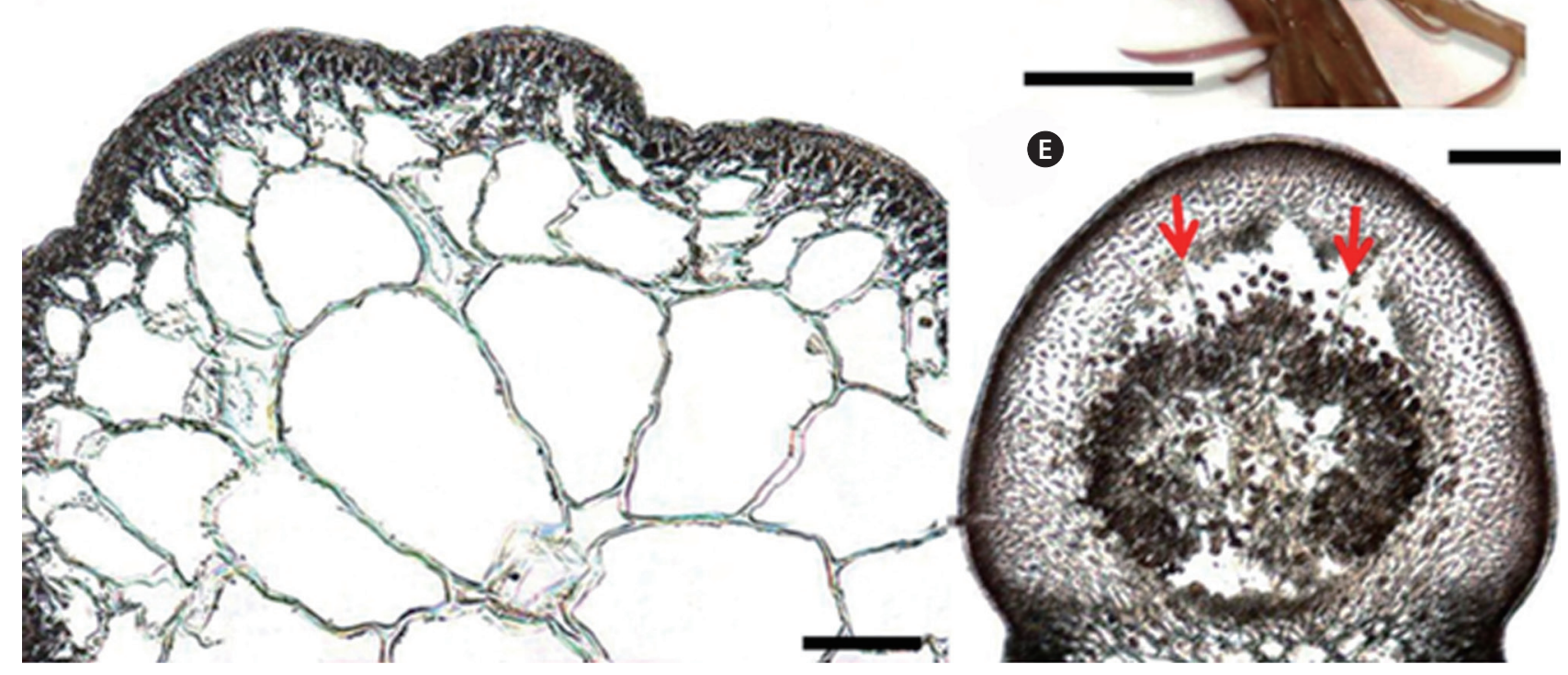

Fig. 3. Gracilaria sp. (A) Herbarium specimen collected from Matou, Sanya, Hainan in January 29, 2010. (B) Shape of markedly constricted branches bearing many cystocarps. (C) The apical part of the branches tapering gradually toward apex. (D) Transverse section of the main axis showing the abrupt transition in medullary cell size and small-celled cortex. (E) Vertical section of cystocarp showing two nutritive filaments (arrows). Scale bars represent: A, $3 \mathrm{~cm} ; \mathrm{B} \& \mathrm{C}, 1 \mathrm{~cm} ; \mathrm{D} \& \mathrm{E}, 200 \mu \mathrm{m}$.

analysis (Fig. 6, cox2-3 spacer data not shown). The molecular analysis indicated that this species formed the independent lineage and closely related to G. salicornia (6.7\% divergence) as a sister species. Further investigation is required to identify this specimen precisely.

\section{Gracilariopsis bailiniae J. Zhang et B. M. Xia (Fig. 4)}

Description. Plants are 15-20 cm long, solitary or caespitose, arising from a small discoid holdfast (Fig. 4A). The thallus is cylindrical, $1.4-1.6 \mathrm{~mm}$ in diameter with 
A
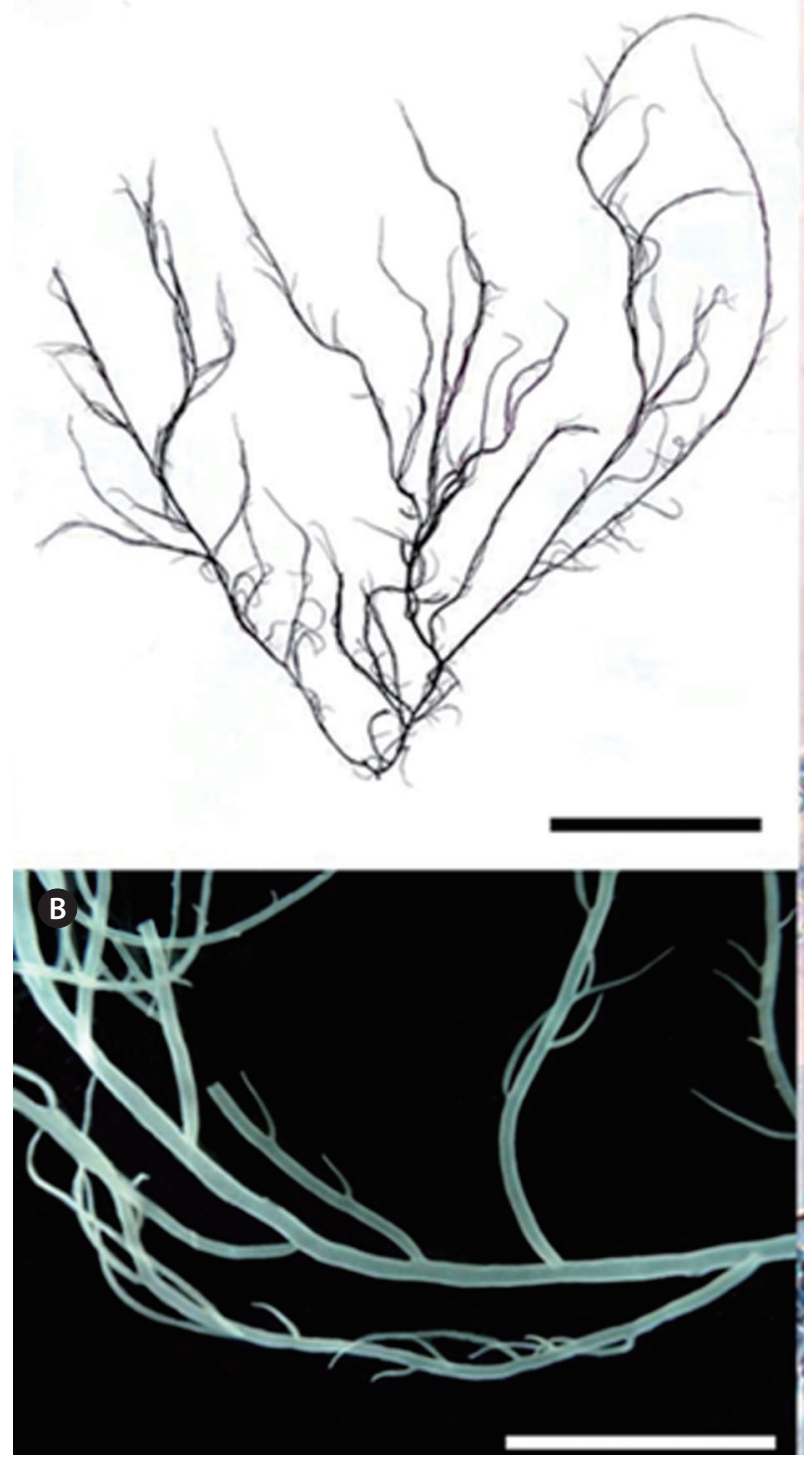

C

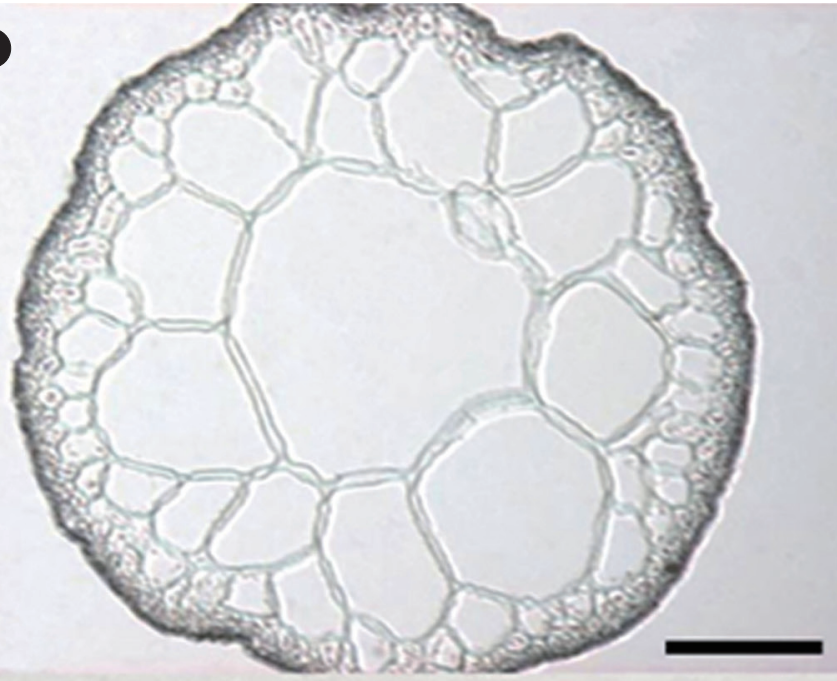

D

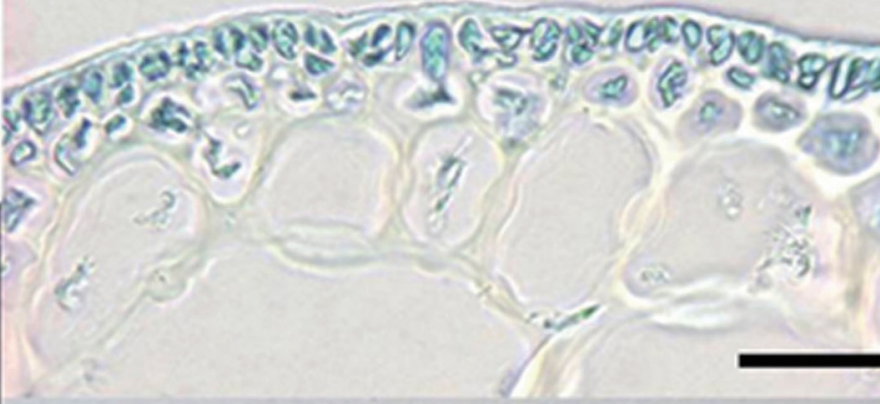

E

Fig. 4. Gracilariopsis bailiniae J. Zhang et B. M. Xia. (A) Herbarium specimen collected from Yulin harbour, Sanya, Hainan in January $31,2010$. (B) Shape of branches and terminal branchlets showing non-constricted them at the base. (C \& D) Transverse section of the branch showing the abrupt transition in medullary cell size and small cortical cells. (E) Transverse section of the branchlet showing a cruciately divided tetrasporangia. Scale bars represent: $A, 5 \mathrm{~cm} ; \mathrm{B}, 2 \mathrm{~cm} ; \mathrm{C}, 300 \mu \mathrm{m} ; \mathrm{D}, 50 \mu \mathrm{m} ; \mathrm{E}, 30 \mu \mathrm{m}$.

2-4 orders of fleshy, brittle, and easily broken branches. Branches are 0.2-0.4 $\mathrm{mm}$ in diameter, gradually tapering toward the apex and are non-constricted at the base (Fig. 4B). The transverse section of the thallus consists of a large medullary cell 400-650 $\mu \mathrm{m}$ in diameter and with walls 10-15- $\mu \mathrm{m}$-thick, surrounded by 2 to 3 layers of small roundish cortical cells with 4-6 $\mu \mathrm{m}$ in diameter (Fig. 4D). The transition of cell size is abrupt from medulla to cor- tex (Fig. 4C). Tetrasporangia are scattered over the surface of branches, ranging from 25-30 × 30-35 $\mu \mathrm{m}$ in diameter, and cruciately divided (Fig. 4E).

Type locality. Yinggehai, Hainan Island, Guangdong Province, China.

Distribution. Asia (Ohno et al. 1999).

Remarks. Gracilariopsis bailiniae Zhang et Xia (1991) was originally described in Yinngehai, Hainan Island as 
Gracilaria heteroclada Zhang et Xia (1988), based on its mix of long branches and short spine-like branchlets. Gracilaria heteroclada was later transferred to the genus Gracilariopsis, as Gp. heteroclada (Zhang et Xia) Zhang et Xia by Abbott et al. (1991). However, Zhang and Xia proposed the name Gracilariopsis bailiniae instead of Gracilaria heteroclada Zhang et Xia (1988), because this specific name was used a homonym of Gracilaria heteroclada (Montagne) J. Feldman et G. Feldmann (1943). This species is distributed over a narrow region in Hainan and the Philippines (Zhang and Xia 1988, Ohno et al. 1999). Regarding the spermatangial configuration, Gp. bailiniae resembles Gp. chorda Holmes and Gp. lemaneiformis (Bory de Saint-Vincent) Greville. However, Gp. bailiniae differs from $G p$. chorda in having small medullary cells, thicker cell walls, and a non-constricted cystocarp base. $G p$. bailiniae can be distinguished from Gp. lemaneiformis in having a thin cuticle, thicker cell wall, small cystocarps and carpospores, and large gonimoblast filament cells with numerous secondary pit connections (Zhang and Xia 1988).

The specimen of Gp. bailiniae was collected from Yulin harbor, Sanya, on January 31, 2010. It was growing in a heavily polluted puddle. Most of the recent molecular data have repeatedly confirmed that Gracilariopsis is a valid genus (Bellorin et al. 2002, Gurgel et al. 2003, Iyer et al. 2005, Kim et al. 2008b, Lin 2008) and 20 species are currently recognized in AlgaeBase (Guiry and Guiry 2011). Phylogenetic analysis based on the $r b c \mathrm{~L}$ sequence resulted in a single clade, including 17 global species of Gracilariopsis (Fig. 6). Three species were not included in this study: Gp. nganii Pham-Hoàng Hô, Gp. phanthietensis Pham-Hoàng Hô, and Gp. rhodotricha E. Y. Dawson. $G p$. nganii and Gp. phanthietensis had previously been reported in Vietnam, but their status had only been recorded in the original description (Hau and Lin 2006). Gp. rhodotricha is also unsuitable in the genus Gracilariopsis because the spermatangia originate in deep pockets, unlike the superficial spermatangia in Gracilariopsis (Hau and Lin 2006). Thus, we considered every possible species of Gracilariopsis and identified the specimen collected from Hainan as the species Gp. bailiniae.

The Gracilariopsis species in the present study showed high genetic divergence (1.7-9.3\%). Gp. bailiniae was categorized as a separate clade with a strong bootstrap value ( $100 \%$ for ML and BA) and it is identical to Gp. bailiniae from the Philippines (Fig. 6) although the genus Gracilariopsis has a highly conserved in gross and reproductive morphology (Bellorin et al. 2008).

\section{Hydropuntia edulis (S. G. Gmelin) Gurgel et Fred- ericq (Fig. 5)}

Description. Plants are 5-8 cm tall and terete throughout, and grow in tufts from a discoid holdfast (Fig. 5A \& B). Branches are fastigiated, wiry, arranged as either dichotomous or trichotomous, and 0.9-1.0 mm in diameter. Several branches arise from the base of the plant with 4 to 6 orders. Ultimate branches are short and spine-like (Fig. 5C). The medulla consists of 7-9 roundish thin-walled cells, $100-250 \mu \mathrm{m}$ in diameter, and 1 to 2 small cortical cell of $15-20 \mu \mathrm{m}$ in diameter (Fig. 5E). The diameter is gradually decreased from medulla to cortex (Fig. 5D).

Basionym. Fucus edulis S. G. Gmelin 1768.

Type locality. Indonesia.

Distribution. Asia (Ohno et al. 1999), Pacific Islands (Tsuda 1985), Australia (Millar and Xia 1997), India (Rao 1972), Africa (Silva et al. 1996).

Remarks. Hydropuntia edulis (S. G. Gmelin) Gurgel et Fredericq (2004) was originally described from Indonesia as Fucus edulis by Gmelin (1768). Silva (1952) transferred it to the genus Gracilaria based on the nomenclature. Chang and Xia (1963) established the genus Polycaver$n o s a$ based on the type species, $P$. fastigiata, from Hainan Island, China. Wynne (1989), however, merged Polycavernosa with the earlier name, Hydropuntia Montagne (1842), and transferred P. fastigiata to the latter genus. Abbott et al. (1991) again merged Hydropuntia with Gracilaria and treated $H$. fastigiata $(=P$. fastigiata) as a synonym of G. edulis.

Hydropuntia Montagne was originally described with $H$. urvillei, based on their elaborate compound spermatangial conceptacles (Wynne 1989). Hydropuntia has been validated by Fredericq and Norris (1985) on the basis of its production of gonimoblasts that not initiated directly from the fusion cell, its basal nutritive filaments, its early cystocarp cavity development and ramified fusion cells. Gurgel and Fredericq (2004) confirmed the independence of the genus Hydropuntia in Gracilariaceae, and finally transferred G. edulis to the genus Hydropuntia.

Hydropuntia edulis was collected from Qingshui bay, Sanya, on January 29, 2010. It was growing on a cliff directly exposed to waves. In the phylogenetic tree of this study, the clade Hydropuntia formed a well-supported monophyletic group including the type species $\mathrm{H}$. urvil$l e i$, even though two species of Gracilaria were included in the same clade (Fig. 6). The Hainan specimen does not have reproductive organs, but the $r b c \mathrm{~L}$ sequences were identical to H. edulis from the Philippines with a strong bootstrap value ( $100 \%$ for ML and BA). 

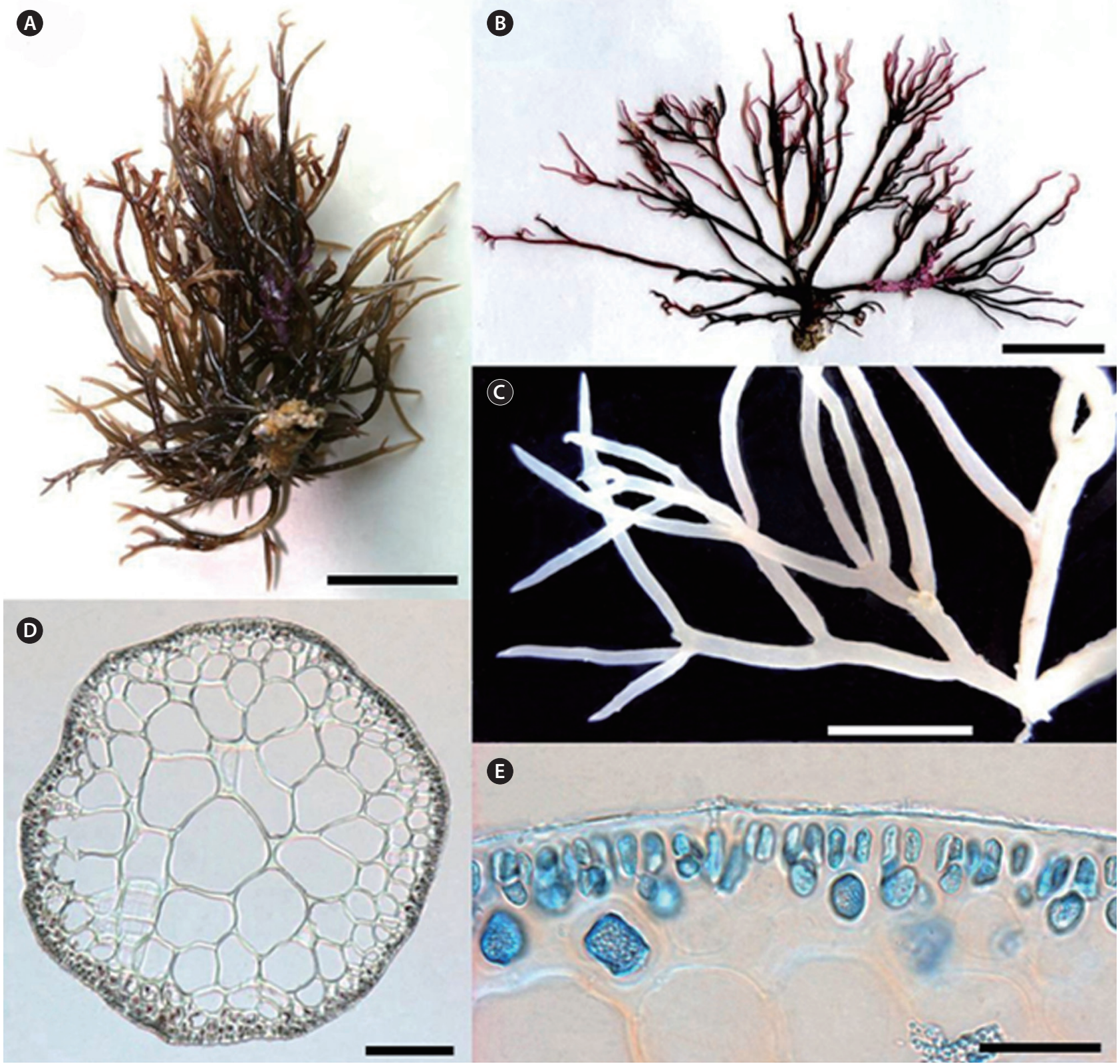

E

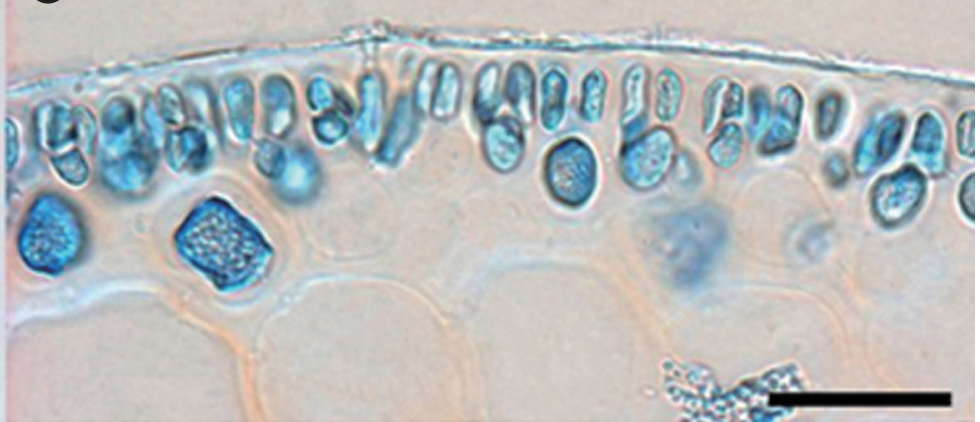

Fig. 5. Hydropuntia edulis (S. G. Gmeli) Gurgel et Fredericq. (A \& B) Living and dried specimen collected from Qingshui bay, Sanya, Hainan in January 29, 2010. (C) Shape of the branches with acute apex. (D \& E) Transverse section of the branch showing the gradual transition in medullary to cortex cell size. Scale bars represent: A, $3 \mathrm{~cm} ; \mathrm{B}, 5 \mathrm{~cm} ; \mathrm{C}, 1 \mathrm{~cm} ; \mathrm{D}, 200 \mu \mathrm{m} ; \mathrm{E}, 30 \mu \mathrm{m}$.

\section{CONCLUSION}

Among the 1,171 base pairs analyzed, 688 were constant, 483 were variable, and only 414 were parsimonyinformative. No insertion or deletion mutations were found in the $r b c \mathrm{~L}$ sequences, permitting unambiguous alignment of all sequences. The phylogenetic relationships of the five Hainan gracilarian species were deter- mined through ML and BA analyses of the $r b c \mathrm{~L}$ sequence data. The phylogenetic trees of ML and BA (data not shown) produced the same topology from a dataset (Fig. 6) and included three genera Gracilaria, Hydropuntia, and Gracilariopsis. Three species belong to the genus Gracilaria (G. salicornia, G. tenuistipitata, and Gracilaria sp.), one belongs to Gracilariopsis (Gp. bailiniae), and the other belongs to Hydropuntia (H. edulis). rbcL sequences 


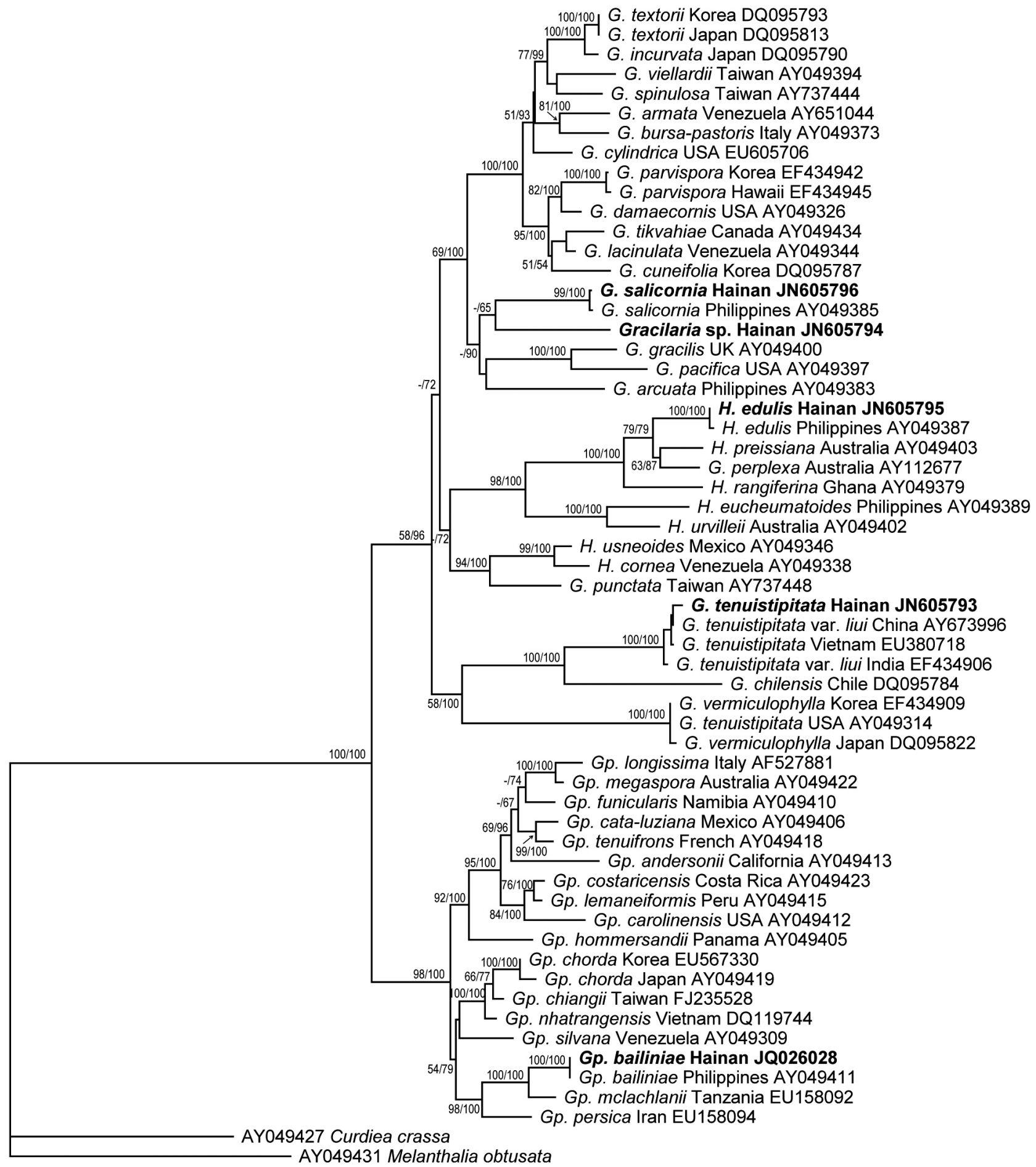

0.1

Fig. 6. Maximum likelihood phylogenetic tree of the family Gracilariaceae estimated using $r b c L$ sequence data. Numbers above each clade represent maximum likelihood bootstrap values and Bayesian posterior probabilities, respectively. Species name of the boldface type are shown the specimens from Hainan Island, China. Scale bar represents: substitutions / site. 
in the genus Gracilaria revealed interspecific genetic diversity of 1.1-9.4\% (including 20 specimens of 17 species) with $69 \%$ for ML and $100 \%$ for BA bootstrap values. The genus Gracilariopsis was clearly separated from Gracilar$i a$ with strong bootstrap values (98\% for ML and $100 \%$ for BA), and an interspecific diversity of $1.7-9.3 \%$ (including 19 specimens of 18 species). The genus Hydropuntia clade was categorized as a sister group to Gracilaria with 2.110.6\% interspecific divergence (including 10 specimens of 9 species), but this clade has no ML bootstrap support. In the same manner, the generic status of Hydropuntia is still doubtful when considering both morphological and molecular data (Bellorin et al. 2002, Gargiulo et al. 2006). The clade of $G$. tenuistipitata has low bootstrap support for ML (58\%) contrary to its strong support of BA (100\%). Gurgel and Fredericq (2004) suggested that morphologically distinct and well-defined species usually have more than $2 \%$ interspecific $r b c \mathrm{~L}$ sequence divergence. In this study, the Gracilaria and Gracilariopsis clades had low interspecific genetic distances, $\geq 1.1 \%$ in Gracilaria and $\geq 1.7 \%$ in Gracilariopsis. Therefore, it is necessary to perform a comprehensive investigation including phylogenetic analysis of several taxa before final conclusions can be made regarding the taxonomy of this group.

This study represents the first molecular contribution to the taxonomy of gracilarioid algae from Hainan Island. The $r b c \mathrm{~L}$ sequence data permitted us to solve the taxonomic position of a number of gracilarioid species, which has been difficult to identify using a classic morpho-anatomical approach only. These results also confirm the known distribution and phylogeny of the gracilarian species in China. Further sampling is required determining the true phylogenetic status of the gracilarioid species reported from the Asia-Pacific region.

\section{ACKNOWLEDGEMENTS}

We thank Prof. J. H. Lee for helping collection of samples. This work was supported by a National Research Foundation of Korea grant, funded by the Korean government (2011-0003313).

\section{REFERENCES}

Abbott, I. A., Zhang, J. \& Xia, B. 1991. Gracilaria mixta, sp. nov. and other western Pacific species of the genus (Rhodophyta: Gracilariaceae). Pac. Sci. 45:12-27.

Agardh, C. A. 1820. Icones algarum ineditae. Vol. Fasc. 1. Ex
Officina Berlingiana, sumtibus Auctoris, Lund, pp. 1-4.

Bellorin, A. M., Buriyo, A., Sohrabipour, J., Oliveira, M. C. \& Oliveira, E. C. 2008. Gracilariopsis mclachlanii sp. nov. and Gracilariopsis persica sp. nov. of the Gracilariaceae (Gracilariales, Rhodophyceae) from the Indian Ocean. J. Phycol. 44:1022-1032.

Bellorin, A. M., Oliveira, M. C. \& Oliveira, E. C. 2002. Phylogeny and systematics of the marine algal family Gracilariaceae (Gracilariales, Rhodophyta) based on small subunit rDNA and ITS sequences of Atlantic and Pacific species. J. Phycol. 38:551-563.

Chang, C. F. \& Xia, B. 1963. Polycavernosa, a new genus of the Gracilariaceae. Stud. Mar. Sin. 3:119-126.

Chang, C. F. \& Xia, B. 1976. Studies on Chinese species of Gracilaria. Stud. Mar. Sin. 11:91-166.

Dawson, E. Y. 1954. Notes on tropical Pacific marine algae. Bull. South. Calif. Acad. Sci. 53:1-7.

Feldmann, J. \& Feldmann, G. 1943. Additions à l'etude de la flore des algues marines de l'Algérie. Bull. Soc. Hist. Nat. Afr. Nord 33:230-245.

Fredericq, S. \& Hommersand, M. H. 1989. Proposal of the Gracilariales ord. nov. (Rhodophyta) based on an analysis of the reproductive development of Gracilaria verrucosa. J. Phycol. 25:213-227.

Fredericq, S. \& Norris, J. N. 1985. Morphological studies on some tropical species of Gracilaria Grev. (Gracilariaceae, Rhodophyta): taxonomic concepts based on reproductive morphology. In Abbott, I. A. \& Norris, J. N. (Eds.) Taxonomy of Economic Seaweeds with Reference to Some Pacific and Caribbean Species. University of California, California Sea Grant College Program, La Jolla, CA, pp. 137-155.

Gargiulo, G. M., Morabito, M., Genoves, G. \& De Masi, F. 2006. Molecular systematics and phylogenetics of Gracilariacean species from the Mediterranean Sea. J. Appl. Phycol. 18:497-504

Gavio, B. \& Fredericq, S. 2002. Grateloupia turuturu (Halymeniaceae, Rhodophyta) is the correct name of the nonnative species in the Atlantic known as Grateloupia doryphora. Eur. J. Phycol. 37:349-359.

Gmelin, S. G. 1768. Historia fucorum. Petropoli, St. Petersburg, $245 \mathrm{pp}$.

Greville, R. K. 1830. Algae britannicae, or descriptions of the marine and other inarticulated plants of the British islands, belonging to the order Algae: with plates illustrative of the genera. MacLachlan \& Stewart, Edinburgh, $218 \mathrm{pp}$.

Guillemin, M. -L., Akki, S. A., Givernaud, T., Mouradi, A., Valero, M. \& Destombe, C. 2008. Molecular characterisation and development of rapid molecular methods to iden- 
tify species of Gracilariaceae from the Atlantic coast of Morocco. Aquat. Bot. 89:324-330.

Guiry, M. D. \& Guiry, G. M. 2011. AlgaeBase. World-wide electronic publication, National University of Ireland, Galway. Available from: http://www.algaebase.org. Accessed Aug 9, 2011.

Gurgel, C. F. D. \& Fredericq, S. 2004. Systematics of the Gracilariaceae (Gracilariales, Rhodophyta): a critical assessment based on $r b c \mathrm{~L}$ sequence analyses. J. Phycol. 40:138-159.

Gurgel, C. F. D., Liao, L. M., Fredericq, S. \& Hommersand, M. H. 2003. Systematics of Gracilariopsis (Gracilariales, Rhodophyta) based on $r b c \mathrm{~L}$ sequence analyses and morphological evidence. J. Phycol. 39:154-171.

Hall, T. A. 1999. BioEdit: a user-friendly biological sequence alignment editor and analysis program for Windows 95/98/NT. Nucleic Acids Symp. Ser. 41:95-98.

Hau, L. N. \& Lin, S. -M. 2006. Gracilariopsis nhatrangensis (Gracilariaceae, Rhodophyta), a new marine red alga from Nhatrang, southern Vietnam. Bot. Stud. 47:329 $-337$.

Iyer, R., Tronchin, E. M., Bolton, J. J. \& Coyne, V. E. 2005. Molecular systematics of the Gracilariaceae (Gracilariales, Rhodophyta) with emphasis on Southern Africa. J. Phycol. 41:672-684.

Kim, M. S., Kim, M., Terada, R., Yang, E. C. \& Boo, S. M. $2008 a$. Gracilaria parvispora is the correct name of the species known as G. bursa-pastoris in Korea and Japan. Taxon 57:231-237.

Kim, M. -S., Yang, E. C. \& Boo, S. M. 2006. Taxonomy and phylogeny of flattened species of Gracilaria (Gracilariceae, Rhodophyta) from Korea based on morphology and protein-coding plastid $r b c \mathrm{~L}$ and $p s b \mathrm{~A}$ sequences. Phycologia 45:520-528.

Kim, M. S., Yang, E. C., Kim, S. Y., Hwang, I. K. \& Boo, S. M. 2008b. Reinstatement of Gracilariopsis chorda (Gracilariaceae, Rhodophyta) based on plastid $r b c \mathrm{~L}$ and mitochondrial coxl sequences. Algae 23:209-217.

Kim, M. S., Yang, M. Y. \& Cho, G. Y. 2010. Applying DNA barcoding to Korean Gracilariaceae (Rhodophyta). Cryptogam. Algol. 31:387-401.

Lin, S. -M. 2008. Morphological and phylogenetic studies of Gracilariopsis chiangii, new species (Gracilariaceae, Rhodophyta), an alga presently known as Gracilaria chorda in Taiwan. Raffles Bull. Zool. Suppl. 19:19-26.

Meneses, I. \& Abbott, I. A. 1987. Gracilaria and Polycavernosa (Rhodophyta) from Micronesia. Micronesica 20:187200.

Millar, A. J. K. \& Xia, B. 1997. Studies on terete species of Australian Gracilaria. In Abbott, I. A. \& Norris, J. N. (Eds.)
Taxonomy of Economic Seaweeds with Reference to Some Pacific and Caribbean Species. Vol. 6. University of California, California Sea Grant College System, La Jolla, CA, pp. 103-109.

Montagne, C. 1842. Prodromus generum specierumque phycearum novarum, in itinere ad polum antarcticum... ab illustri Dumont d'Urville peracto collectarum, notis diagnosticis tantum huc evulgatarum, descriptionibus verò fusioribus nec no iconibus analyticis jam jamque illustrandarum. apud Gide, editorem, Paris, 16 pp.

Ohno, M., Terada, R. \& Yamamoto, H. 1999. The species of Gracilaria from Vietnam. In Abbott, I. A. (Ed.) Taxonomy of Economic Seaweeds with Reference to Some Pacific Species. Vol. 7. University of California, California Sea Grant College System, La Jolla, CA, pp. 99-111.

Posada, D. \& Crandall, K. A. 1998. Modeltest: testing the model of DNA substitution. Bioinformatics 14:817-818.

Rao, M. U. 1972. On the Gracilariaceae of the seas around India. J. Mar. Biol. Assoc. India 14:671-696.

Ronquist, F. \& Huelsenbeck, J. P. 2003. MrBayes 3: Bayesian phylogenetic inference under mixed models. Bioinformatics 19:1572-1574.

Rueness, J. 2005. Life history and molecular sequences of Gracilaria vermiculophylla (Gracilariales, Rhodophyta), a new in troduction to European waters. Phycologia 44:120-128.

Saunders, G. W. 2009. Routine DNA barcoding of Canadian Gracilariales (Rhodophyta) reveals the invasive species Gracilaria vermiculophylla in British Columbia. Mol. Ecol. Resour. 9:140-150.

Silva, P. C. 1952. A review of nomenclatural conservation in the algae from the point of view of the type method. Univ. Calif. Publ. Bot. 25:241-323.

Silva, P. C., Basson, P. W. \& Moe, R. L. 1996. Catalogue of the benthic marine algae of the Indian Ocean. Univ. Calif. Publ. Bot. 79:1-1259.

Swofford, D. L. 2002. PAUP*: phylogenetic analysis using parsimony ( ${ }^{2}$ and other methods). Version 4.0b10. Sinauer Associates, Sunderland, MA.

Terada, R., Kawaguchi, S., Masuda, M. \& Phang, S. M. 2000. Taxonomic notes on marine algae from Malaysia. III. Seven species of Rhodophyceae. Bot. Mar. 43:347-357.

Terada, R. \& Shimada, S. 2005. Taxonomic note on Gracilaria articulata Chang et Xia (Gracilariales, Rhodophyta) from Okinawa, Japan. Cryptogam. Algol. 26:77-89.

Tsuda, R. T. 1985. Gracilaria from Micronesia: key, list and distribution of the species. In Abbott, I. A. \& Norris, J. N. (Eds.) Taxonomy of Economic Seaweeds with Reference to Some Pacific and Caribbean Species. Vol. 1. University of California, California Sea Grant College Program, La 
Jolla, CA, pp. 91-92.

Witherell, A. F., Millar, A. J. K. \& Kraft, G. T. 1994. Taxonomic studies of the genus Gracilaria (Gracilariales, Rhodophyta) from Australia. Aust. Syst. Bot. 7:281-352.

Wynne, M. J. 1989. The re-instatement of Hydropuntia Montagne (Gracilariaceae, Rhodophyta). Taxon 38:476-479.

Xia, B. 1985. Gracilaria from China: key, list and distribution of the species. In Abbott, I. A. \& Norris, J. N. (Eds.) Taxonomy of Economic Seaweeds with Reference to Some Pacific and Caribbean Species. Vol. 1. University of California, California Sea Grant College Program, La Jolla, CA, pp. 71-76.

Xia, B. 1986. On Gracilaria salicornia (C. Agardh) Dawson. Chin. J. Oceanol. Limnol. 4:100-107.

Zhang, J. \& Xia, B. 1988. On two new Gracilaria (Gigartinales, Rhodophyta) from South China. In Abbott, I. A. (Ed.) Taxonomy of Economic Seaweeds with Reference to Some
Pacific and Caribbean Species. Vol. 2. University of California, California Sea Grant College Program, La Jolla, CA, pp. 127-129.

Zhang, J. \& Xia, B. 1991. A new specific name in the genus Gracilaria. Chin. J. Oceanol. Limnol. 9:290.

Zhang, J. \& Xia, B. 1992. Studies on two new Gracilaria from South China and a summary of Gracilaria species in China. In Abbott, I. A. (Ed.) Taxonomy of Economic Seaweeds with Reference to Some Pacific and Caribbean Species. Vol. 3. University of California, California Sea Grant College, La Jolla, CA, pp. 195-206.

Zhang, J. \& Xia, B. 1994. Three foliose species of Gracilaria from China. In Abbott, I. A. (Eds.) Taxonomy of Economic Seaweeds with Reference to some Pacific Species. Vol. 4. University of California, California Sea Grant College, La Jolla, CA, pp. 103-110. 